\title{
Promoting community collaboration in counter-terrorism: Do social identities and perceptions of legitimacy mediate reactions to procedural justice policing?
}

\author{
Natasha S. Madon and Kristina Murphy
}

Griffith Criminology Institute

Adrian Cherney

The University of Queensland

This is a pre-print version of the paper published in the British Journal of Criminology.

Citation: Madon, N. S., Murphy, K., \& Cherney, A. (2016). Promoting community

collaboration in counter-terrorism: Do social identities and perceptions of legitimacy

mediate reactions to procedural justice policing? British Journal of Criminology, azw053. doi:10.1093/bjc/azw053.

\begin{abstract}
The present study examines whether procedural justice policing can promote Muslims' willingness to cooperate with police in terrorism prevention. Using survey data from 800 Australian Muslims, we show that Muslims value procedural justice when it comes to working with police to prevent terrorism. We also examine whether social identification processes or perceptions of police legitimacy explain why procedural justice promotes Muslims' willingness to work with police. The findings suggest that despite the salience of identity within the current political discourse about terrorism and Islam, perceptions of police legitimacy appear to have a stronger bearing on Muslims' predicted behaviour. We consider
\end{abstract}


the implications of our findings for theories in the procedural justice field and for counterterrorism policy and practice.

Keywords: Counter-terrorism, cooperation, procedural justice policing, legitimacy, social identity

In the post 9/11 era there has been a change in the way that authorities respond to threats of domestic terrorism. The global political discourse on counter-terrorism has given the impression that certain groups in society ought to be more closely monitored because they risk becoming radicalised or pose a threat to public safety. In the West the Muslim diaspora in particular has come under scrutiny (Aly 2007; Cherney and Murphy 2015). This heightened attention has brought greater surveillance of members of the Muslim community ${ }^{1}$, including greater numbers of police stops and searches on the streets, and greater scrutiny at airports and borders (Blackwood et al. 2013a; Blackwood et al. 2013b; Choudhury and Fenwick 2011; Mythen et al. 2009; Parmar 2011).

Within this political climate, local police agencies have been tasked with preventing and responding to possible terrorist acts at the local level. In practice, taking on counterterrorism policing has meant adopting more intelligence-led strategies. The problem though is that such a shift in focus towards more intrusive and surveillance-based policing risks alienating Muslims and thus undermining their willingness to aid police in preventing and investigating radicalisation and terrorism (Vermeulen and Bovenkerk 2012). Some research conducted in the U.K., U.S., Canada and Australia has questioned the extent to which members of the Muslim community are willing to voluntarily collaborate with police after experiencing intrusive police surveillance (Blackwood et al. 2013a; Cherney and Murphy

\footnotetext{
${ }^{1}$ The term 'Muslim community' can be seen as problematic as it does not adequately capture the diversity of cultures, languages, and religious sects that can be associated with it, suggesting instead that there exists a homogenous voice. However, while we acknowledge the limitations of the term, we elect to use it here in a purposefully broad sense in absence of a better way of describing all the members of this community.
} 
2015; Cherney and Murphy 2013; Huq et al. 2011; Spalek and Imtoual 2007; Tyler et al. 2010).

It is within this space that the current paper positions itself, seeking to examine how willing Muslims are to work collaboratively with police in the fight against terrorism. Using survey data collected from 800 Australian Muslims we examine how perceptions of procedural justice policing - a style of policing that emphasises strong and positive relations between police and citizens - shapes how Muslims view police and their willingness to

support and work with them in counter-terrorism. We then examine whether Muslims' 'social identity' or perceived 'police legitimacy' mediates their reactions to procedural justice. In doing so, our work extends current research by simultaneously evaluating which of these two factors has greater explanatory strength for explaining the procedural justice-cooperation relationship. Before presenting the results, we first present a brief review of relevant literature informing our study. The theoretical framework guiding our study is then presented, followed by the methodology and findings.

\section{The policing of Muslim communities post 9/11}

In Western nations, authorities have placed increasing pressure on members of the Muslim community to report suspected radicalisation and suspicious terrorist-related activity. At the same time they have also been the target of increased surveillance from police and security agencies (Spalek and Imtoual 2007). This duality of attention, both as sources of intelligence as well as the focus of suspicion, has contributed to many members of the Muslim community feeling 'under siege' simply because they are Muslim. As Cherney and Murphy (2015) argue, these feelings of being 'under siege' are related to greater levels of uneasiness among the Muslim diaspora, potentially undermining their bonds with mainstream society 
(also see Blackwood et al. 2013a). The concern with the weakening of such bonds is that it can lead to disaffection toward authorities and society more generally, with it potentially contributing to Muslim radicalisation and a reduced willingness among Muslims to cooperate with authorities (Cherney and Murphy 2015; Hafez and Mullins 2015).

Research evidence suggests that overly intrusive counter-terrorism policies and practices can marginalise Muslim communities. For example, Parmar's (2011) study of predominantly Asian Muslim men in London found that for many, increased police contact led to a decline in trust in the police, with some suggesting they were less likely to contact police in the future. Similar concerns have been raised by Muslims in Australia (Cherney and Murphy 2013). Cherney and Murphy (in-press) found that Muslim Australians who reported feeling more "under siege" from counter-terrorism policies were less likely to indicate that they trusted the police. Distrust in police was subsequently linked to Muslims' self-reported reluctance to work collaboratively with police in their counter-terrorism efforts.

While much recent research focuses on how official counter-terrorism policies can result in 'suspect communities' (see for example Breen-Smyth 2014; Sentas 2014), less attention has been paid to the effectiveness of community-based initiatives that seek to engage Muslim community members in the fight against home-grown terrorism (Vermeulen and Bovenkerk 2012). Increasingly, authorities around the world are realising that partnering with the Muslim community is crucial to address radicalisation of Muslim youth and to prevent violent extremism (Cherney and Hartley 2015; Huq 2013; Vermeulen 2014). At the centre of such engagement programs is the desire to build partnerships between Muslim communities and law enforcement. However, in practice, these 'partnerships' also run the risk of being viewed as one-directional, with members of the Muslim community seen solely as a source of intelligence. The opportunity for meaningful engagement and the opportunity to allow Muslims a voice in the process can be lost if the Muslim community sees such 
attempts at engagement as superficial (Cherney and Murphy 2015). What this suggests is that authorities need to tread very carefully in their efforts to engage with Muslim communities in a way that is not seen to be disingenuous or manipulative.

While 'what works' with terrorism prevention and enforcement is still unclear, it has been strongly argued that 'hard' counter-terrorism initiatives driven solely by heavy enforcement crackdowns will not be as effective as 'softer' approaches which partner with the community to address these issues (Huq et al. 2011). As Tyler (2012) notes, working without the cooperation of members of the public makes the work of law enforcement all the more challenging. The need for public assistance in prevention and investigation can arguably be ever more pertinent to counter-terrorism policing, as motivations behind terrorist acts differ from the motivations that elicit general crime. This makes potential targets more difficult to assess, and suspects more challenging to identify. As Tyler, Shulhofer, and Huq (2010) argue, when compared to other types of crime, terrorism related offences occur less

frequently, making it much more difficult to investigate without the support of the public. This demonstrates the need for policing practices that facilitate greater 'buy in' from members of the Muslim community. Tyler et al. (2010) and Tyler (2012) argue that police strategies based on procedural justice can help facilitate greater levels of cooperation in counter-terrorism policing and offers a more positive and productive approach for encouraging members of the public to work with police to counter terrorism.

\section{Procedural Justice Policing: A more positive approach to engaging with Muslim communities?}

The willingness of the public to cooperate with police in their counter-terrorism efforts is important because such behaviour is solely voluntary in nature. The police cannot always use coercion, deterrence, or punishment to force people to report suspicious behaviour occurring 
in their community. Thus, as Tyler (2012) notes, authorities seek to promote proactive behaviour amongst citizens. This is particularly pertinent in a counter-terrorism context where the population under scrutiny also tends to feel marginalised by authorities. As a result, what authorities must rely on is an approach that engages with the Muslim community and builds trust and public support of policing efforts (Cherney and Hartley 2015).

The procedural justice perspective has been increasingly drawn on to explain how voluntary support for police and other authority figures can be built or maintained (Jackson et al. 2012; Mazerolle et al. 2014; President's Task Force on $21^{\text {st }}$ Century Policing 2015). Highlighted within this literature is the notion that fair treatment and fair procedures will bring greater trust in authorities, leading to greater voluntary cooperation with authorities. Rooted in the work of Thibault and Walker (1975) the procedural justice perspective proposes that the manner in which people are treated by criminal justice actors matters. People respond favourably to signs that authorities use procedural justice. Procedural justice scholars argue that perceptions of fair treatment can be the driving force behind one's willingness to support, engage with, or cooperate with authorities (Jackson et al. 2012).

Often described as the process-based model, procedural justice theory posits that people's views of police and other authorities are related to their interpersonal treatment by these actors. Central to procedural justice is a focus on fair and respectful treatment within a given process or interaction, as well as attention to fair decision-making. People are thought to evaluate encounters with authorities through four key aspects: voice, being shown respect, feeling that one is treated with fairness, and perceiving that there is neutrality in any decisionmaking process. Regardless of an outcome, people are more likely to view an encounter with police favourably if they feel that they were able to share their side on the matter; that the process was conducted in a fair manner, with officers maintaining citizen's respect and dignity, and ultimately if citizens feel that police decisions were made in the absence of bias 
(Jackson et al. 2012; Murphy et al. 2014). When people feel that they have received procedural justice in these ways, they will be more obligated to cooperate with police. As such, while police may not always be able to control whether people like an outcome associated with their actions (i.e. being investigated, questioned, arrested, or charged) they can play a key role in ensuring that they treat citizens in fair and respectful ways (Sunshine and Tyler 2003). This is what makes procedural justice policing such an appealing approach to use in encounters with members of the public. This might be especially so for members of the population who feel marginalised or 'under siege' (Cherney and Murphy in-press).

Findings from policing studies show that procedurally just treatment from police can enhance people's trust in police (e.g., Gau 2014; Murphy et al, 2014), can enhance feelings of satisfaction with an encounter with police (eg., Jonathan-Zamir et al. 2015), can enhance perceptions of the police as legitimate and entitled to be obeyed (e.g., Tyler and Fagan 2008), can increase people's acceptance of police decisions (e.g., Tyler and Wakslak 2004), can enhance the social bonds between police and citizens (eg., Bradford 2014; Tyler and Jackson 2014), and importantly, can enhance citizens' willingness to cooperate with police requests and engage with police in their crime fighting efforts (e.g., Reisig and Lloyd 2009; Murphy et al. 2015; White et al. 2015). Some studies have even reported that procedural justice policing can promote greater public compliance with the law (e.g., Barkworth and Murphy 2015; Reisig et al. 2014).

More recently, a small but growing number of studies have examined the effectiveness of procedural justice specifically as it relates to counter-terrorism policing. When looking at the experiences of Muslims in the U.K., the U.S., and Australia, the quality of treatment Muslims receive from police appears to matter for predicting Muslims'selfreported willingness to cooperate with counter-terrorism investigations in the future (Cherney and Murphy 2013; Cherney and Murphy in-press; Huq et al. 2011; Murray et al. 2015; Tyler 
et al. 2010). Together, the results of these studies show that procedural justice policing may prove particularly effective in engaging Muslim communities in the fight against terror.

\section{Why does procedural justice promote cooperation?: Legitimacy and social identity as important mediating variables}

It is important to understand from a theoretical perspective why procedural justice promotes people's willingness to cooperate with police. One important aspect of procedural justice theory is the role that legitimacy plays in fostering people's law-abiding behaviours. Studies have shown that legitimacy is an important mediating factor in the procedural justice/cooperation relationship (Jackson et al. 2012). Procedural justice scholars have argued that people feel compelled to cooperate with authorities if they view them as legitimate.

Murphy, Bradford and Jackson (2015) suggest that when citizens recognise the legitimacy of an authority they believe that the authority has the right to ask members of the public to comply with laws and to act in the best interests of society. This can include police encouraging citizens to work with authorities to prevent crime and/or terrorism. Legitimacy thus results in promoting an internal obligation to bring one's behaviour into line with what is expected of a good citizen in society. It is this internal buy in that promotes support for authorities even when people may disagree with the overarching agenda of the authority (Mazerolle et al. 2014). In other words, Muslims may disagree with the policy agenda set by the government when dealing with terrorism, or they may question the approach police use to investigate their community. But if they view police as legitimate they will feel obligated to support police in their counter-terrorism efforts because they believe it is socially appropriate to do so. Hence, research suggests that authorities can best motivate cooperative behaviour through building public perceptions of their legitimacy, and legitimacy is best promoted when authorities use procedural justice. 
An alternative model that has been used to explain the link between procedural justice and cooperation is the group engagement model (Tyler and Blader 2003). Rooted in social psychology, the group engagement model argues that people are more likely to 'engage' or cooperate with authorities when they identify with the authority or the group the authority represents. This is because the exercise of fair treatment by an authority promotes an individual's social identification with the power holder (i.e., the police) and the group that the power holder represents (i.e., members of broader society). According to social identity theory (Tajfel and Turner 2004) - the theory on which the group engagement model is based-strong identification activates the roles, norms and responsibilities expected of an individual within that group. In a law enforcement context, adhering to the dominant group includes cooperating with authority figures (i.e., police), respecting authorities, and being a law-abiding citizen. Key to this identity-based argument is the idea that procedural justice communicates to people information about their status and value within society. Being held in good standing encourages one to align one's beliefs and behaviour with the wider group. It also encourages people to support and work with groups they identify strongly with. In other words, identification will motivate cooperation with legal authorities because members of social groups are motivated to behave in ways that are expected of them from other group members and because they draw value, status and self-worth from these roles and relationships (Tajfel and Turner 2004).

While fair treatment is related to positive group engagement and ultimately cooperation, unfair treatment can also have negative implications on identity formation (Tyler and Blader 2003). Those who feel as though they are being treated disrespectfully will view such treatment as reflective of their worth and status within a group. Such feelings may lead to an unwillingness to engage with members of the group and may lead to withdrawal of cooperation from the authorities that represent the dominant group in society. Social identity 
processes might be particularly relevant in the present context given that many Muslims living in the West feel increasingly under siege, with their loyalties to the countries in which they reside questioned and their religion criticised as antithetical to Western secular values (Kabir 2007; Kundnani 2014; Cherney and Murphy in-press). It is argued this has only increased a sense of isolation among Muslim communities and created an atmosphere conducive to Islamophobia (Heath-Kelly 2013; Morgan and Poynting 2012; Patton 2014).

In such a context one might expect procedurally just policing to enhance Muslims' identification with Western societies and key institutions because such fair treatment from society's representatives (i.e. police) communicates that Muslims are valued and respected members of the community. Stronger bonds should in turn promote their willingness to act in the best interests of the wider community, which may include reporting suspected radicalisation or terrorist threats to police.

\section{The Study}

While promoting somewhat different explanations for how cooperation is promoted, both the legitimacy model and the social identity model have the same result: they both theorise why procedural justice can promote people's willingness to cooperate with authorities. Existing research has mainly examined the relationship between procedural justice, legitimacy and cooperation/compliance or has focused on the connection between procedural justice, social identity and cooperation/compliance. In these studies, legitimacy and social identity are seldom examined together. To date, only two studies have empirically examined how both social identity and legitimacy mediate the effect of procedural justice simultaneously, with one study looking at this with respect to traffic offences and the other examining compliance in a taxation context (see Bradford et al. 2015; Murphy et al. 2015). Both of these prior studies examined legal compliance behaviour as the outcome variable, and both studies 
revealed that social identity processes played a very important mediating role in the procedural justice/compliance relationship. In fact, in the Murphy et al. study, identity, not legitimacy was found to be the stronger mediator of the relationship.

The present study is the first to examine both the social identity and legitimacy models simultaneously in the context of counter-terrorism policing. We specifically focus on counter-terrorism policing and Muslims' willingness to work collaboratively with police. We thus focus on cooperation as the outcome variable. By evaluating the relative importance of the two mediators simultaneously we will be able to better understand why Muslims might be willing to cooperate with authorities, and importantly, which of the police legitimacy or social identification explanations linking procedural justice to cooperation carries more weight. Voluntary cooperative behaviour is substantially different to compliance behaviour. There are no laws stipulating one must report concerns or suspicious activities to authorities. Hence, given the need for public cooperation with police to prevent acts of terror, it is important to develop an understanding of whether legitimacy or social identity is the better mediator of the procedural justice/cooperation relationship. Given growing Islamophobia in the West, and feelings of ostracism among Muslim communities (Breen-Smyth 2014), we speculate that social identity processes may carry particular salience in the counter-terrorism policing context. Drawing on the literature above, we propose four hypotheses:

1. Procedural justice is positively linked to identity, perceptions of police legitimacy, and self-reported willingness to cooperate with police in counter-terrorism.

2. Legitimacy will mediate the effect of procedural justice on cooperation.

3. Social identification will mediate the relationship between procedural justice and cooperation. 
4. Given the mounting scrutiny and vilification of Muslims in Western society, we propose that social identity may be the more important mediator of the procedural justice/cooperation relationship than police legitimacy.

\section{Methodology}

The data used in this paper was collected as part of a larger project on Muslim Australians' perceptions of counter-terrorism laws and policing practices. While the project incorporated both a survey and focus group design, this paper only draws on data collected from the survey. The 'Being Muslim in Australia Survey' canvassed a number of issues with Muslim respondents including views on Australian foreign policy, feelings of being under siege, as well as perceptions of social inclusion. The survey further sought to assess Muslim Australians' positions on terrorism and support for counter-terrorism initiatives. Respondents were asked about contact with police in the past twelve months, as well as their broader assessments of police legitimacy and police treatment of Muslim Australians within the context of counter-terrorism. Respondents were further asked a number of questions related to their willingness to cooperate with police to prevent terrorism and radicalisation. Muslims' identification with Australia and their religion were further assessed.

Due to the specific population of interest here, a unique sampling strategy was employed. A survey company with expertise in recruiting and delivering surveys to hard-toreach ethnic minority groups was engaged. Muslim interviewers, fluent in Arabic as well as English, were employed to field the survey and also to promote a greater sense of comfort amongst respondents to share their views on potentially sensitive and politically charged topics in their language of choice.

In order to create a sampling frame, an 'ethnic name based system' was employed to sample Muslims from the larger Australian population. A list of 525 common Muslim 
surnames was generated and used to then search the Australian Electronic White Pages telephone directory. From this, a list of 8,765 individual names was constructed by sampling names from the telephone directory in Brisbane, Sydney and Melbourne. Such an approach excludes those who may not have a publicly listed telephone number, land line, or Muslim women who may have married outside of the Muslim community and changed their surnames. However, research has shown that this approach (over random-digit dialling) is an effective way to create a sampling frame when seeking to survey members of small minority groups (Murphy et al. 2013). Further, as the present study was interested in Muslim Australians more generally and not a specific sect or ethnicity, this approach was suitable.

Using the list of individuals, interviewers commenced randomly contacting potential participants. Brisbane, Sydney, and Melbourne were chosen due to the large number of Muslims residing in these urban centres. On initial phone contact, interviewers asked to speak to the person in the home who was at least 18 years of age and would be celebrating their birthday next. Respondents were then asked if they considered themselves to be Muslim, establishing eligibility for study participation. If eligible, arrangements were then made for the in-person interview to be held in a public location (e.g. shopping centre, café, library). Between June and August 2014, face-to-face interviews were conducted with a total of 800 Muslim Australian respondents, with 200 from Brisbane, and 300 each from Sydney and Melbourne. After adjusting for invalid cases and other out-of-scope participants $(\mathrm{N}=3566)$ an overall response rate of $18 \%$ was achieved. While such an overall response rate can be regarded as low, it is consistent with previous research in Australia with similar ethnic minority samples (Murphy et al. 2013). A significant amount of work to win the trust and confidence of participants had to be undertaken by the Muslim interviewers, who reported a high level of suspicion and apprehension from potential respondents about the research project and what they would be asked. As such, this response rate is not surprising given the 
sampling strategy and nature of the study, which may cause Muslims to be reluctant to share their opinions about terrorism.

The average age of study participants was 35 years. When compared to the overall Australian Muslim population, 15 to 24 year olds were over-represented in the current sample, while those 25 to 61 were slightly under-represented. Australian-born respondents were over-represented when compared to the proportion of Australian to non-Australian-born Muslims in Australia. Female Muslims were also slightly over-represented compared to population estimates. In terms of the breakdown by religious sect, the large majority of respondents indicated that they were Sunni Muslim (69\%) with the remainder identifying as Shia Muslim (31\%). This sample composition matches the broader Muslim population in Australia (Hassan 2015). While 99\% of respondents indicated that they were Australian citizens, the majority indicated that they were from Lebanese, Pakistani, or Indonesian ancestry. Finally, with respect to religious practices, more than half of respondents reported that they attended a mosque weekly (for further information see Murphy, Cherney and Barkworth 2015).

\section{Scale Construction}

While the Being Muslim in Australia Survey measured a number of factors associated with views on policing practices, only the survey items that are relevant to this study are highlighted below. All survey items presented were measured on a five-point Likert scale ( $1=$ strongly disagree to $5=$ strongly agree). Table 1 contains the list of questions used to construct scales used in this paper.

\section{Procedural Justice}


Ten survey items measuring voice, respect, neutrality and trustworthiness were used to measure procedural justice in the policing of terrorism. These items were adapted from Huq et al. (2011). The multi-item measure was found to be highly reliable (alpha $=.95)$. A higher score on the scale indicates greater perceptions that police use procedural justice when dealing with members of the Muslim community when investigating and policing terrorism.

\section{Police Legitimacy}

Eight items were used to create a measure of perceptions of police legitimacy (alpha $=.85$ ) with a higher score indicating greater confidence in the legitimacy of police (see Table 1 for specific questions). As legitimacy itself has been argued to be a nuanced construct (Jackson et al., 2011), a number of elements of police legitimacy were included, including: a) trust and confidence in police; b) obligation to comply with police directives/orders; and c) seeing the police as morally aligned with one's values.

\section{Social Identity}

While it is likely that an individual may identify with a number of different social groups in society, for the purposes of the current study, Muslims' strength of identity with Australia was assessed. Based on previous work by Murphy (2013), four items were used to construct a measure of Australian identity (alpha $=.81)$. A higher score indicates stronger identification with Australia.

\section{Cooperation with police in counter-terrorism reporting}

Muslims' self-reported willingness to voluntary cooperate with police in counter-terrorism was measured using six items on a 1 (very unlikely) to 5 (very likely) scale (alpha $=.95$ ); a higher score indicates greater self-reported willingness to cooperate with police. The questions were adopted from those used in previous procedural justice studies (e.g., Huq et al. 
2011; Tyler et al. 2010). It should be noted that these questions are not based on what respondents have or have not reported to police, but rather what they believe they would do if faced with a similar situation in the future.

\section{Control Variables}

A number of demographic and other control variables were also measured in order to examine individual differences in self-reported willingness to cooperate with police. These include: age, gender ( $1=$ male; 2 = female), level of educational attainment (ranging from $1=$ no/limited formal schooling to $10=$ having a post-graduate degree), household income (ranging from $1=$ total household income of AUS\$11,000 $-\$ 15,000$ to $20=$ household income of AUS\$111,000 - \$120,000), and frequency of police contact in the past 12 months. The mean scores for some of these control measures, as well as the main scales used, are presented in Table 2.

\section{Results}

\section{Factor Analysis}

An exploratory principal components factor analysis using varimax rotation was employed to examine the underlying factor structure of our measures. The results of the factor analysis are presented in Table 1. All of the variables loaded as expected onto their respective factors, with the eigenvalues suggesting a fifth possible factor. However, given our interest in four variables, we elected to force four factors. There appears to be a few instances of crossloading between the procedural justice scale and the cooperation scale. As these constructs are distinct and measure different elements - procedural justice measures an attitude while cooperation measures intended behaviour - the impact of the cross-loading was not seen to be 
a concern. One legitimacy item failed to reach the 0.35 threshold cut-off. We decided to retain the item given it has been used in prior research to measure police legitimacy (Jackson et al. 2011).

[Table 1 here]

\section{Descriptive Statistics}

The means, standard deviations, and correlation coefficients for the scales and control variables used in this paper are presented in Table 2. The high mean score of the police legitimacy measure suggests that respondents hold positive views about the legitimacy of the police. The fairness by which police exercise their authority in the context of counterterrorism (i.e., procedural justice) was viewed less positively. A high mean score was found for the Australian identity scale, suggesting that respondents in the sample appear to subscribe strongly to an Australian identity. With respect to self-reported willingness to cooperate with police, it appears that, on average, those in the sample are neither unlikely nor likely to report terrorism related activities to police (the mean score was close to the midpoint of the five-point scale).

The correlation results suggest that cooperative behaviour is positively related to perceptions of procedural justice, police legitimacy, and identity, and negatively related to frequency of police contact in the past year. This suggests that those who perceive the police as treating Muslims with respect and fairness or perceive the police as legitimate are more willing to voluntarily contact the police to report terrorist threats. Similarly, having a stronger Australian identity was found to be associated with a greater willingness to report incidents to police. 
[Table 2 here]

\section{Regression Analysis}

A hierarchical regression analysis was conducted to examine which variables predict Muslims' willingness to collaborate with police in a counter-terrorism context. The control variables were entered in the first step, followed by procedural justice at step 2 and the Australian identity and police legitimacy variables at step 3. As shown in Table 3, we find in step 1 that age, gender, and contact with the police each predict self-reported willingness to cooperate with police. When the procedural justice variable is added to the analysis in step 2, age is no longer a significant predictor, while gender, police contact, and procedural justice are found to predict voluntary cooperation with police. The findings suggest that women and those who have had fewer prior contacts with police, and those who think police use procedural justice when dealing with Muslims in counter-terrorism efforts indicate more willingness to work with police to combat terrorism. In the final step, the demographic variables are no longer found to predict police cooperation, but recent contact with police, perceptions of procedural justice, legitimacy, and Australian identity are all found to predict cooperation. Procedural justice is the strongest predictor of cooperation, followed by legitimacy, identity and police contact. Respondents who feel the police treat Muslims fairly, see police as more legitimate, strongly identify with Australia, and who have had fewer prior contacts with police, are more likely to indicate they would report terrorism related threats or offences to police. Interestingly, the strength of the procedural justice effect diminished slightly, but not fully, on entry of the legitimacy and identity variables, suggesting the legitimacy and identity variables partially mediated the effect of procedural justice on cooperation. Sobel tests confirmed the significance of these mediation effects $(z=12.26, p<$ .001 for legitimacy and $\mathrm{z}=11.05, \mathrm{p}<.001$ for identity, respectively). 
[Table 3 here]

\section{Structural Equation Model}

Structural equation modelling (SEM) was undertaken to examine the relationships between all of the key variables of interest concurrently ${ }^{2}$. The model fit statistics suggest the data fit the model well. The SEM, as shown in Figure 1, shows that procedural justice is positively related to both the identity and legitimacy variables. That is, if police are seen to be using procedural justice when engaging Muslims they are viewed as more legitimate, and their social identification with Australia is bolstered. In other words, procedural justice appears to communicate important symbolic messages about one's identity, and our findings suggest that fair treatment is associated with enhanced identification with Australia. In fact, $47 \%$ of the variation in the legitimacy variable, and $24 \%$ of the identity variable can be explained solely by Muslims' perceptions of procedural justice. Like in the regression analysis, procedural justice was also directly associated with cooperation; Muslims who were more likely to believe police use procedural justice were more willing to cooperate with police.

Where the findings of the SEM diverge from the findings of the regression analysis is in the relationship between identity and cooperation. While both legitimacy and identity were found to predict Muslims' willingness to cooperate with police in the regression model, of the two variables only legitimacy predicted willingness to cooperate with police in the SEM; those who viewed police as more legitimate said they would be more willing to work with police to combat terrorism. Australian identity was not a significant predictor of cooperation in our SEM.

\footnotetext{
${ }^{2}$ Note that the legitimacy and identity constructs were allowed to co-vary in the model to control for the statistical effect of each on cooperation. The correlation between the two latent constructs in the model was insignificant $(\mathrm{r}=.08, \mathrm{p}=.07)$.
} 
Hence, our model reveals that legitimacy appears to be the only significant mediator in the procedural justice/cooperation relationship. However, Figure 1 shows that there is still a significant direct path between procedural justice and cooperation. This suggests that legitimacy is only a partial mediator of the procedural justice/cooperation relationship in our study. The indirect effect of procedural justice on cooperation, via legitimacy, was significant $(\beta=0.19, \mathrm{p}<0.05)$, suggesting that procedural justice has some of its effect on cooperation through legitimacy. In other words, legitimacy is a significant partial mediator of the procedural justice-cooperation relationship. However, procedural justice is by far the strongest predictor of Muslims' willingness to cooperate with police in counter-terrorism. A total of $57 \%$ of the variation in the cooperation variable can be explained by procedural justice and legitimacy. While identity was not found to be a significant predictor of cooperation in the SEM, the remainder of our findings support those of our regression model, but provide a more nuanced understanding of how each of the variables in the model is related to each other.

[insert Figure 1 about here]

\section{Discussion}

Our study had two overarching aims. First, it sought to examine the relationship between procedural justice policing and Muslims' willingness to work with police in terrorism prevention. Second, it sought to test the relative importance of the 'legitimacy model' versus the 'identity model' for explaining why procedural justice is related to public willingness to work collaboratively with police. Given mounting Islamophobia in the West, we were particularly interested in testing whether social identity processes would matter more than perceptions of police legitimacy in a counter-terrorism context. 
We found support for our first hypothesis; procedural justice was found to be positively associated with Muslims' identity with Australia, with their perceptions of police legitimacy, and with their self-reported willingess to cooperate with police in efforts to prevent terrorism. We also found support for the second hypothesis, with Muslims' perceptions of police legitmacy partially mediating the relationship between procedural justice and cooperation. Interestingly, support was not found for our third or fourth hypotheses, suggesting that identity processes may not be as salient as we had intially anticipated. We hypothesized that identity would be a more important mediator of the procedural justice/cooperation relationship than legitimacy. This was not found to be the case. Instead, legitimacy was found to be the sole mediator between procedural justice and cooperation with police, while Australian identity was not a signficant factor. These findings thus lend greater support to the 'legitimacy' model. In other words, in the current policing context, procedural justice promotes Muslims' willingness to cooperate with police because it enhances their perceptions of the legitimacy of police. If Muslims view police as legitimate they will be more willing to cooperate with an authority they see as legitimate.

While identity was not found to directly predict cooperation in the SEM, we should note that it was strongly related to Muslims' perceptions of procedural justice. Procedural justice policing therefore appears to carry weight in influencing how connected Muslims feel to mainstream society. This finding provides support for the importance of fair police procedures and treatment, not just as it directly relates to willingess to cooperate with police, but also in facilitating a stronger sense of identity with a nation state. Given that governments in the West are struggling to find ways to improve feelings of inclusion and belonging among Muslim communities, procedural justice policing appears to be a useful tool to achieve this. The role of police in promoting a sense of social inclusion should not be underestimated given that police are both symbolic and institutional representatives of the state. 
The findings presented here on the relationship between procedurally just treatment and self-reported willingess to cooperate with police also point to the importance of law enforcement agencies reconsidering 'hard' approaches to counter-terrorism. Counterterrorism approaches can take a number of forms, from police raids on one end of the spectrum to police-community engagement initiatives on the other. Hence, there are a variety of opportunities for police to engage in procedurally just practices. Heavy-handed policing and the over-surveillance of certain groups runs the risk of eroding the perceived legitimacy of institutional authorities, which can in turn lead to the withdrawal of cooperation by certain group members (Cherney and Hartley 2015). As Tyler et al. (2010) argue, "government management of terrorist threats may be as important as terrorism itself in determining future levels of violence" (372; see also English 2010). In this way, the kinds of police responses to radicalisation and terrorism, and the ways in which these responses are perceived by members of the Muslim community, are important considerations. Given that the ways in which people and their communities are treated by police can predict an individual's selfreported willingness to cooperate with police, a counter-terrorism approach that is experienced as unjust by Muslims may seek to work against, rather than with police efforts. In contrast, fair and inclusive practices which maintain citizens' rights can foster greater willingess to initiate contact with police, to share information, and to report incidents to police. This only helps to improve police engagement efforts.

\section{How to achieve greater procedural justice in counter-terrorism policing}

As mentioned, counter-terrorism approaches vary and involve more than just police conducting raids and breaking down civilians' doors. Rather, they include engagement activities, which we argue ought to include trust and rapport building with members of the 
Muslim community (Cherney and Hartely 2015; Murray et al. 2015; Spalek 2013). The findings of the present study further the argument that such ends can be achieved through the application of procedural justice to the policing of terrorism. As outlined at the outset of this paper, the primary facets of procedual justice can be distilled down to four key elements: voice, respect, fairness, and neutrality. Using these principles as a starting point to improve impressions of counter-terrorism practices, a number of recommendations arise.

Firstly, in their interactions with police, people often seek to have an opportunity to share their view on a matter. Individuals seek to have a voice prior to the point of any decision being reached. While it may not always be practical for police to consult individuals when there is an imminent and serious threat of violence, features of counter-terrorism policing do provide opportunities for this to occur (Cherney and Hartely 2015). This is particularly the case for situations that involve efforts to promote partnerships between police and Muslim communities, moblising Muslim leaders to work with authorities to counter violent extremism and to faciliate the sharing of information. In such contexts it is important that police strive to implement initiatives that grant members of the Muslim community a voice on how they envisage their role as co-producers of counter-terrorism strategies.

A second element of procedural justice policing involves enhanncing citizens' feelings of being respected during encounters with police. The quality of the treatment that people receive from police is significantly related to feelings of being respected as an individual and linked to perceptions that one's rights are being maintained. Perceptions of respect can be fostered by police adopting some simple cross-cultural sensitivity practices. For instance, when possible, officers removing shoes when entering a Mosque or a Muslim family's home can serve to demonstrate greater respect for Islamic cultural traditions and practices (Cherney and Murphy in-press). 
Third, procedural justice policing that ensures that officers follow due-process rules and are polite, whether in a police- or citizen-initiated encounter, can be effective in the counter-terrorism context by instilling a sense of fairness of process. Ensuring that officers demonstrate professional behaviour can promote perceptions that Muslims' rights are being respected and that police have their best interests at heart. In a counter-terrorism context this kind of respectful treatment potentially helps communicate to Muslims that they are regarded as being on the 'same side' as police; an important element proposed by the group engagement model, and an important part of building identification with police.

Finally, the fourth element of procedural justice is that of the perceived neutrality of officers. Here, people are more inclined to view an outcome favourably if they feel that decisions are made based on evidence and facts rather than based on personal opinions and biases (Mazerolle et al. 2014). The problem is that enhancing perceptions of neutrality poses a greater challenge in a counter-terrorism context where Muslims in general have been identified as at-risk of radicalisation and as a potential source of homegrown terrorism. Such discourse, frequently taken up in the media and present in political rhetoric on the subject, has left little ambiguity in the minds of many members of the Muslim community about how they are viewed by society more broadly, and by the police in particular (Birt 2009; BreenSmith 2014; Cherney and Murphy 2015; Morgan and Poynting 2012; Parmar 2011). Such impressions can make conveying neutrality problematic, as individuals may presume that they are being targetted by authorities simply due to their affiliation with the Islamic faith (Cherney and Hartley 2015). For Muslim people who are questioned by authorities in the absense of any wrong doing, the motives of these authorities can be perceived as anything but neutrual (Blackwood 2015; Cherney and Murphy in-press). This may also be true of interactions where police indeed have reason to question individuals. However, taking this into account and acknowledging that individuals may feel targeted at the outset, if police 
maintain fair, professional practices when engaging with members of the Muslim community, they may be able to minimize the negative effects of such encounters. Research on racial profiling has found that the quality of the treatment that people receive from police can minimze perceptions of racial profiling (see Tyler 2003). Similar approaches may also be effective in the counter-terrorism context.

None of the above recommendations suggest that police should abandon their role as investigators of terrorism threats. Rather the desired ends of achieving greater success in these investigations may be achieved by applying principles of procedural justice to existing interactions that police are having with members of the Muslim community on a day-to-day basis. By committing to procedural justice, police may be better positioned to engage with members of the Muslim community for the purpose of encouraging Muslims' collaboration with police in the future. Such behavior is ultimately a key ingredient to preventing terrorism.

\section{Limitations and Future Research}

While our study has revealed some important findings, we should acknowledge the limitations of our study. As with any cross-sectional survey data of the kind used here, we cannot make causal claims about the relationships between our variables. An additional limitation is the possibility of a selection bias within our sample. While the response rate achieved here is not surprising given the subject topic, it does pose potential problems for the validity of our conclusions. A possible implication of this is that the current sample may not include the perceptions of those who are particularly disengaged (e.g. young Muslim males) and who may not have elected to participate in the survey as a result. Those who agreed to participate in this study may have been more likely to cooperate with police in the first place, may have held more positive views on counter-terorism policing, and may have identified 
more strongly with Australia. It is important that our findings are considered with this in mind.

Finally this study only examined a limited number of variables as predictors of Muslims' willingness to cooperate with police to prevent terrorism. It is possible that other predictors, not used here, could be important in determining who will or will not collaborate with police. Such variables might include attitudes to the government's foreign policies, religiosity such as level of Mosque attendence, or prior experiences with the police (Murphy, Cherney and Barkworth 2015; Cherney and Murphy in-press). Future research might ask members of the Muslim community about their impressions of police efforts to foster greater collaboration and engagement with their community, in order to better gauge how these 'softer' counter-terrorism approaches are being perceived by members of the community.

\section{Conclusion}

The findings of the present study contribute to a greater understanding of the possible drivers of Muslims' willingness to cooperate with police in the counter-terrorism context. Our findings suggest that within a counter-terrorism context the theoretical explanation that has the strongest effect in explaining why procedural justice is important to fostering cooperation with police is the legitimacy model. Police legitimacy was found to be the only significant mediator between procedural justice and willingess to report incidents to police. Identity did not mediate the relationship in our study. A legitimate police force is one that Muslims have greater confidence and trust in, one which inspires an obligation to work collaboratively with police, and is one that is seen to share the goals of the community.

While identity did not predict cooperation in our model, this is not to say identity processes should be ignored. Given the role that police play, not only as law enforcement 
officers, but also as symbolic representatives of the state, they can play an important function in social identity formation. Police officers play an integral role in fostering inclusion in society and encouraging people to come forward with information. Blackwood et al. (2013b) found that members of the Muslim community in Scotland were most distressed by police suspision and questioning of them, particularly when it was seen to tacitly express an outgroup status. The interactions with police communicated a lack of recognition of belonging in Scotland, with such treatment diminishing any sense of a 'Scottish identity' that was held as significant to them (also see Blackwood 2015). Hence, the nature of police-citizen interactions can greatly influence whether people perceive their status as being a valued member of society.

Considering the present findings, it appears that counter-terrorism policing is more than an issue of securitization. Our research shows that approaches that ensure members of the Muslim community view police as legitimate are likely to have greater success in promoting voluntary collaboration and engagement with police counter-terrorism initiatives. Procedural justice can help police achieve such ends.

\section{Funding Information}

This work was supported by the Australian Research Council (Grant Number DP130100392). 


\section{REFERENCES}

ALY, A. (2007). 'Australian Muslim Responses to the Discourse on Terrorism in the Australian Popular Media', Australian Journal of Social Issues, 42: 27-40

BARKWORTH, J. M. and MURPHY, K. (2015). 'Procedural justice policing and citizen compliance behaviour: the importance of emotion', Psychology, Crime and Law, 21: 254-73.

BLACKWOOD, L. (2015). 'Policing Airport Spaces: The Muslim Experience of Scrutiny', Policing, DOI:10.903/police/pav024.

BLACKWOOD, L., HOPKINS, N. and REICHER, S. (2013a). 'I know who I am, but who do they think I am? Muslim Perspectives on Encounters with Airport Authorities', Ethnic and Racial Studies, 36: 1090-1108.

BLACKWOOD, L., HOPKINS, N. and REICHER, S. (2013b). 'Turning the Analytic Gaze on "Us", European Psychologist, 18: 245-52.

BIRT, Y. (2009) 'Promoting Virulent Envy: Reconsidering the UK's Terrorist Prevention Strategy', RUSI Journal, 154: 52-8.

BRADFORD, B. (2014). 'Policing and Social Identity: Procedural Justice, Inclusion and Cooperation Between Police and Public’, Policing and Society, 24: 22-43.

BRADFORD, B., HOHL, K., JACKSON, J., and MACQUEEN, S. (2015). 'Obeying the Rules of the Road: Procedural Justice, Social Identity, and Normative Compliance', Journal of Contemporary Criminal Justice, 31: 171-91.

BRADFORD, B., MURPHY, K., and JACKSON, J. (2014). 'Officers as Mirrors: Policing, Procedural Justice, and the (Re)Production of Social Identity', British Journal of Criminology, DOI:10.1093/bjc/azu021

BREEN-SMYTH, M. (2014). 'Theorising the 'Suspect Community': Counterterrorism, Security Practices and the Public Imagination', Critical Studies on Terrorism, 7: 22340.

CHERNEY, A. and MURPHY, K. (2013). 'Policing Terrorism with Procedural Justice: The Role of Police Legitimacy and Law Legitimacy', Australian and New Zealand Journal of Criminology, DOI:0004865813485072.

CHERNEY, A. and MURPHY, K. (2015). 'Being a 'Suspect Community'in a Post 9/11 World-The Impact of the War on Terror on Muslim Communities in Australia', Australian and New Zealand Journal of Criminology, DOI:0004865815585392.

CHERNEY, A. and HARTLEY, J. (2015). 'Community Engagenent to Tackle Terrorism and Violent Extremism: Challenges, Tensions, and Pitfalls', Policing and Society, DOI:10.1080/10439463.2015.1089871. 
CHERNEY, A. and MURPHY, K. (in-press). 'Police and Community Cooperation in

Counter-Terrorism: Evidence and Insights From Australia', Studies in Conflict \& Terrorism.

CHOUDHURY, T. and FENWICK, H. (2011). 'The Impact of Counter-Terrorism Measures on Muslim Communities', International Review of Law, Computers and Technology, 25: $151-81$.

ENGLISH, R. (2010). Terrorism: How to Respond. Oxford: Oxford University Press.

GAU, J. (2014). 'Procedural Justice and Police Legitimacy: A Test of Measurement and Structure', American Journal of Criminal Justice, 39: 187-205.

HAFEZ, M. and MULLINS, C. (2015). 'The Radicalization Puzzle: A Theoretical Synthesis of Empirical Approaches to Homegrown Extremism', Studies in Conflict \& Terrorism, 38: 958-75.

HEATH-KELLY, C. (2013). 'Counter-Terrorism and the Counterfactual: Producing the 'Radicalisation' Discourse and the UK PREVENT Strategy', The British Journal of Politics and International Relations, 15: 394-415.

HUQ, A. Z., TYLER, T. R. and SCHULHOFER, S. J. (2011). 'Mechanisms for Eliciting Cooperation in Counterterrorism Policing: Evidence from the United Kingdom', Journal of Empirical Legal Studies, 8: 728-61.

HUQ, A.Z. (2013). 'The Policitcal Psychology of Counterterrorism', Annual Review of Law and Social Science, 9: 71-94.

HASSAN, R. (2015). Australian Muslims: A Demographic, Social and Economic Profile of Muslims in Australia. International Centre for Muslim and Non-Muslim Understanding, University of South Australia.

JACKSON, J., BRADFORD, B., HOUGH, M. and MURRAY, K. (2011). 'Policing by Consent and Public Compliance with the Law: Notes on Legal Legitimacy and Cynicism', in A. Crawfod and A. Hucklesby, eds, Legitimacy and Compliance in Criminal Justice. London: Routledge.

JACKSON, J., BRADFORD, B., STANKO, B., and HOHL, K. (2012). Just Authority?: Trust in the Police in England and Wales. London: Routledge.

JONATHAN-ZAMIR, T., MASTROFSKI, S. D. and MOYAL, S. (2015). 'Measuring Procedural Justice in Police-Citizen Encounters', Justice Quarterly, 32: 845-71.

KABIR, N. (2007). 'Muslims in Australia: The Double Edge of Terrorism', Journal of Ethnic and Migration Studies, 33: 1277-97.

KUNDANI, A. (2014). The Muslims are Coming! Islamophobia, Extremism, and the Domestic War on Terror. London: Verso. 
MAZEROLLE, L., SARGEANT, E., CHERNEY, A., MURPHY, K., BENNETT, S., ANTROBUS, E. and MARTIN, P. (2014). Procedural Jusice and Legitimacy in Policing. New York: Springer.

MORGAN, G. and POYNTING (eds) (2012). Global Islamophobia: Muslims and Moral Panic in the West. London: Ashgate.

MURPHY, K. (2009). 'Public satisfaction with police: The importance of procedural justice and police performance in police-citizen encounters', Australian and New Zealand Journal of Criminology, 42: 159-78.

MURPHY, K., CHERNEY, A. and BARKWORTH, J. M. (2015a). Avoiding Community Backlash in the Fight Against Terrorism: Research Report. Australia Research Council Discovery Project DP130100392. University of Queensland and Griffith University.

MURPHY, K., CHERNEY, A., WICKES, R., MAZEROLLE, L. and SARGEANT, E. (2013). The Community Capacity Survey-Face-to-face Ethnic Minority Interviews: Methodology and Preliminary Findings. ARC Centre for Excellence in Policing and Security, University of Queensland.

MURPHY, K., MAZEROLLE, L., and BENNETT, S. (2014). 'Promoting trust in police: Findings from a randomized experimental field trial of procedural justice policing' Policing \& Society, 24: 405-424.

MURPHY, K., SARGEANT, E. and CHERNEY, A. (2015b). 'The Importance of Procedural Justice and Police Performance in Shaping Intentions to Cooperate with the police: Does Social Identity Matter?', European Journal of Criminology, DOI:1477370815587766.

MURPHY, T., BRADFORD, B. and JACKSON, J. (2015c). 'Motivating Compliance Behavior Among Tax Offenders: Procedural Justice or Deterrence?', Criminal Justice and Behavior, DOI:10.1177/0093854815611166.

MURRAY, A., MUELLER-JOHNSON, K. and SHERMAN, L.W. (2015). 'Evidence-Based Policing of U.K. Muslim Communities: Linking Confidence in the Police with Area Vulnerability to Extremism', International Criminal Justice Review, DOI:10.1177/1057567715574384.

MYTHEN, G., WALKLATE, S. and KHAN, F. (2009). " I'm a Muslim, but I'm not a Terrorist': Victimization, Risky Identities and the Performance of Safety', British Journal of Criminology, 49: 736-54.

PARMAR, A. (2011). 'Stop and Search in London: Counter-Terrorist or Counter-Productive? Policing and Society, 21: 369-82.

PATTON, C. (2014). 'Multicultural Citizenship and Religiosity: Young Australian Muslims Forging a Sense of Belonging After 9/11', Journal of Intercultural Studies, 35: 107-22. 
PRESIDENTS TASK FORCE ON $21^{\text {ST }}$ CENTURY POLICING (2015). Final Report of the President's Task Force on $21^{\text {st }}$ Century Policing. Washington, DC: Office of Community Oriented Policing Services.

REISIG, M. D. and LLOYD, C. (2009). 'Procedural Justice, Police Legitimacy, and Helping the Police Fight Crime: Results From a Survey of Jamaican Adolescents', Police Quarterly, 12: 42-62.

REISIG, M.D., TANKEBE, J. and MESKO, G. (2014). 'Compliance with the Law in Slovenia: The Role of Procedural Justice and Police Legitimacy', European Journal on Criminal Policy and Research, 20: 259-76.

SENTAS , V. (2014). Traces of Terror: Counter Terror Law, Policing, and Race. Oxford: Oxford University Press.

SPALEK, B. (2013). Terror Crime Prevention with Communities. London: Bloomsbury Academic.

SPALEK, B. and IMTOUAL, A. (2007). 'Muslim Communities and Counter-Terror Responses:"Hard" Approaches to Community Engagement in the UK and Australia', Journal of Muslim Minority Affairs, 27: 185-202.

SUNSHINE, J. and TYLER, T. R. (2003). 'The Role of Procedural justice and legitimacy in shaping public support for policing, Law and Society Review, 37, 513-548.

TAJFEL, H. and TURNER, J. C. (2004). The Social Identity Theory of Intergroup Behavior, New York: Psychology Press.

THIBAULT, J.W. and WALKER, L. (1975). Procedural Justice: A Psychological Perspective. NJ: Lawrence Erlbaum.

TYLER, T. R. (2003). 'Procedural Justice, Legitimacy, and the Effective Rule of Law', Crime and Justice, 30: 283-357.

TYLER, T. R. (2006). Why People Obey the Law. Princeton: Princeton University Press.

TYLER, T.R. (2012). 'Toughness vs. Fairness: Police Policies and Practices for Managing the Risk of Terrorism', in Lum, C. and Kennedy, L.W. (eds.), Evidence-Based Counterterrorism Policy (Springer Verlag), 353-363.

TYLER, T. R. and BLADER, S. L. (2003). 'The Group Engagement Model: Procedural Justice, Social Identity, and Cooperative Behavior', Personality and Social Psychology Review, 7: 349-61.

TYLER, T. R. and FAGAN, J. (2008). 'Legitimacy and Cooperation: Why Do People Help the Police Fight Crime in their Communities?', Ohio State Journal of Criminal Law, 6: 231-75. 
TYLER, T. R. and JACKSON, J. (2014). 'Popular Legitimacy and the Exercise of Legal Authority: Motivating Compliance, Cooperation, and Engagement', Psychology, Public Policy, and Law, 20: 78-95.

TYLER, T. R., SCHULHOFER, S. and HUQ, A. Z. (2010). 'Legitimacy and Deterrence Effects in Counterterrorism Policing: A Study of Muslim Americans', Law and Society Review, 44: 365-402.

TYLER, T. R. and WAKSLAK, C. J. (2004). 'PROFILING AND POLICE LEGITIMACY: PROCEDURAL JUSTICE, ATTRIBUTIONS OF MOTIVE, AND ACCEPTANCE OF POLICE AUTHORITY', Criminology, 42: 253-282.

VERMEULEN, F. (2014). 'Suspect Communities - Targeting Violent Extremism at the Local Level: Policies of Engagement in Amsterdam, Berlin, and London', Terrorism and Political Violence, 26:286-306.

VERMEULEN, F. and BOVENKERK, F. (2012). Engaging with Violent Islamic Extremism: Local Policies in Western European Cities. Hague: Eleven International Publishers.

WHITE, M. D., MULVEY, P. and DARIO, L. M. (2015). 'Arrestees' Perceptions of the Police: Exploring Procedural Justice, Legitimacy, and Willingness to Cooperate With Police Across Offender Types', Criminal Justice and Behavior, DOI:10.1177/0093854815602501. 
Table 1. Factor analysis differentiating variables

\begin{tabular}{|c|c|c|c|c|}
\hline \multirow[b]{2}{*}{ Item } & \multicolumn{4}{|c|}{ Factors } \\
\hline & 1 & 2 & 3 & 4 \\
\hline $\begin{array}{l}\text { I. Procedural Justice Scale-When dealing with } \\
\text { people in your community concerning issues of } \\
\text { terrorism, the police... }\end{array}$ & & & & \\
\hline $\begin{array}{l}\text { give people a chance to express their views before } \\
\text { making decisions. }\end{array}$ & 0.74 & & & \\
\hline $\begin{array}{l}\text { make their decisions based upon facts, not their } \\
\text { personal opinions. }\end{array}$ & 0.68 & 0.42 & & \\
\hline $\begin{array}{l}\text { apply the law consistently to everyone, regardless of } \\
\text { who they are. }\end{array}$ & 0.66 & 0.43 & & \\
\hline consider people's views when deciding what to do. & 0.73 & & 0.37 & \\
\hline $\begin{array}{l}\text { take account of the needs and concerns of the people } \\
\text { they deal with. }\end{array}$ & 0.74 & & & \\
\hline respect people's rights. & 0.71 & & & \\
\hline treat people with dignity and respect. & 0.68 & 0.40 & & \\
\hline treat people fairly. & 0.71 & 0.39 & & \\
\hline try to be fair when making decisions. & 0.72 & 0.38 & & \\
\hline are polite when dealing with people. & 0.72 & 0.41 & & \\
\hline $\begin{array}{l}\text { II. Cooperation Scale - If you saw or heard about } \\
\text { the following activities, how likely would you be to } \\
\text { report it to police: }\end{array}$ & & & & \\
\hline $\begin{array}{l}\text { a person saying he/she had joined a group you } \\
\text { consider politically radical. }\end{array}$ & & 0.81 & & \\
\hline $\begin{array}{l}\text { a person visiting Internet chat rooms or Web sites } \\
\text { that support al Qaeda. }\end{array}$ & & 0.83 & & \\
\hline $\begin{array}{l}\text { a person reading religious literature you believe to be } \\
\text { extremist. }\end{array}$ & & 0.84 & & \\
\hline $\begin{array}{l}\text { a person giving money to organisations that people } \\
\text { say are associated with terrorists. }\end{array}$ & & 0.82 & & \\
\hline $\begin{array}{l}\text { a person talking about traveling overseas to fight for } \\
\text { Muslims. }\end{array}$ & & 0.79 & & \\
\hline $\begin{array}{l}\text { a person distributing materials expressing support for } \\
\text { al Qaeda. }\end{array}$ & & 0.74 & & \\
\hline III. Legitimacy Scale & & & & \\
\hline $\begin{array}{l}\text { The way the police act in my community is usually } \\
\text { consistent with the values of people in my } \\
\text { community about what is right and wrong. }\end{array}$ & & & 0.80 & \\
\hline I trust the police in my community. & & & 0.72 & \\
\hline
\end{tabular}




\begin{tabular}{|c|c|c|c|c|}
\hline $\begin{array}{l}\text { My own feelings about what is right and wrong } \\
\text { generally align with how police act in my } \\
\text { community. }\end{array}$ & & & 0.81 & \\
\hline I feel a moral obligation to obey the police. & & & 0.70 & \\
\hline $\begin{array}{l}\text { The police share the same values of ordinary citizens } \\
\text { like me. }\end{array}$ & & & 0.68 & \\
\hline Overall, I obey police with good will. & & & 0.60 & \\
\hline $\begin{array}{l}\text { Police are legitimate authorities entitled to be } \\
\text { obeyed. }\end{array}$ & & & 0.40 & \\
\hline $\begin{array}{l}\text { It is our duty to obey police officers, even when we } \\
\text { do not like the way they treat us. }\end{array}$ & & & $0.31 *$ & \\
\hline IV. Australian Identity Scale & & & & \\
\hline I am proud to be an Australian. & & & & 0.74 \\
\hline I identify strongly with being Australian. & & & & 0.84 \\
\hline $\begin{array}{l}\text { Being an Australian is important to the way I think of } \\
\text { myself as a person. }\end{array}$ & & & & 0.83 \\
\hline I see myself as Australian first and Muslim second. & & & & 0.66 \\
\hline Eigenvalues (before rotation) & 14.68 & 1.98 & 1.95 & 1.29 \\
\hline Explained variance (after rotation) & $22.53 \%$ & $19.89 \%$ & $16.74 \%$ & $11.92 \%$ \\
\hline
\end{tabular}

Note: Extraction method: Principal components analysis with varimax rotation.

Only factors loading $>0.35$ are displayed. * did not reach threshold of .35 . 


\section{Table 2. Descriptive statistics and correlations between measures of interest}

\begin{tabular}{|l|c|c|c|c|c|c|c|c|c|c|c|}
\hline \multicolumn{1}{|c|}{ Measure } & Items & $M$ & SD & 1 & 2 & 3 & 4 & 5 & 6 & 7 & 8 \\
\hline 1.Procedural Justice & 10 & 3.93 & 0.74 & - & & & & & & \\
& & & & & & & & & \\
\hline 2.Police Legitimacy & 8 & 4.08 & 0.54 & $0.68^{* *}$ & - & & & & & \\
\hline 3.Australian Identity & 4 & 3.75 & 0.83 & $0.54^{* *}$ & $0.39^{* *}$ & - & & & & & \\
\hline 4.Cooperation & 7 & 3.48 & 0.77 & $0.73^{* *}$ & $0.62^{* *}$ & $0.46^{* *}$ & - & & & & \\
\hline 5.Gender & 1 & $\mathrm{n} / \mathrm{a}$ & $\mathrm{n} / \mathrm{a}$ & $0.72^{*}$ & $0.09^{*}$ & 0.07 & $0.11^{* *}$ & - & & & \\
\hline 6.Age & 1 & 34.89 & 15.51 & $0.14^{* *}$ & $0.14^{* *}$ & -0.00 & $.16^{* * *}$ & -0.02 & - & & \\
\hline 7.Education & 1 & 5.32 & 2.03 & -0.00 & 0.01 & $0.13^{* *}$ & -0.05 & $-0.11^{* *}$ & $-0.10^{* *}$ & - & \\
\hline 8.Income & 1 & 9.99 & 3.57 & -0.01 & -0.03 & $0.10^{* *}$ & -0.06 & $-0.22^{* *}$ & $-0.12^{* *}$ & $0.53^{* *}$ & - \\
\hline 9.Contact & 1 & 0.40 & 0.92 & $-0.24^{* *}$ & $-0.32^{* *}$ & $-0.15^{* *}$ & $-0.27^{* *}$ & -0.20 & $-0.12^{* *}$ & -0.01 & -0.01 \\
\hline
\end{tabular}

Note: *Indicates a significant relationship at $p<.05$,** indicates a significant relationship at $p<.001$. Higher mean scores indicates

greater levels of procedural justice, police legitimacy, Australian identity, Muslim identity, and cooperation. 
Table 3. Hierarchical regression predicting Muslims' self-reported cooperation with police

\begin{tabular}{|c|c|c|c|c|c|c|}
\hline & \multicolumn{2}{|c|}{ Step 1} & \multicolumn{2}{|c|}{ Step 2} & \multicolumn{2}{|c|}{ Step 3} \\
\hline & $\mathrm{B}(\mathrm{SE})$ & $\beta$ & $\mathrm{B}(\mathrm{SE})$ & $\beta$ & B (SE) & $\beta$ \\
\hline Age & $.01(.00)$ & $.12 * *$ & $.00(.00)$ & .04 & $.00(.00)$ & .04 \\
\hline Gender & $.15(.06)$ & $.10^{*}$ & $.08(.04)$ & $.05^{*}$ & $.07(.04)$ & .04 \\
\hline Education & $-.01(.02)$ & -.02 & $-.00(.01)$ & -.01 & $-.01(.01)$ & -.02 \\
\hline Income & $-.00(.01)$ & -.02 & $-.01(.01)$ & -.03 & $-.01(.01)$ & -.03 \\
\hline Contact & $-.21(.03)$ & $-.25 * *$ & $-.08(.02)$ & $-.10 * *$ & $-.05(.02)$ & $-.06 *$ \\
\hline $\begin{array}{l}\text { Procedural } \\
\text { just. }\end{array}$ & & & $.71(.03)$ & $.70 * *$ & $.54(.04)$ & $.53 * *$ \\
\hline Legitimacy & & & & & $.25(.05)$ & $.18 * *$ \\
\hline $\begin{array}{l}\text { Australian } \\
\text { ID. }\end{array}$ & & & & & $.09(.03)$ & $.10 * *$ \\
\hline $\mathbf{R}^{2}$ & & & & & & \\
\hline Adjusted $\mathbf{R}^{2}$ & & & & & & \\
\hline $\mathbf{R}^{2}$ Change & & & & & & \\
\hline$F$ Change & 16. & & 740 & & & \\
\hline
\end{tabular}

${ }^{*} p<.05 ; * * p<.001$. 


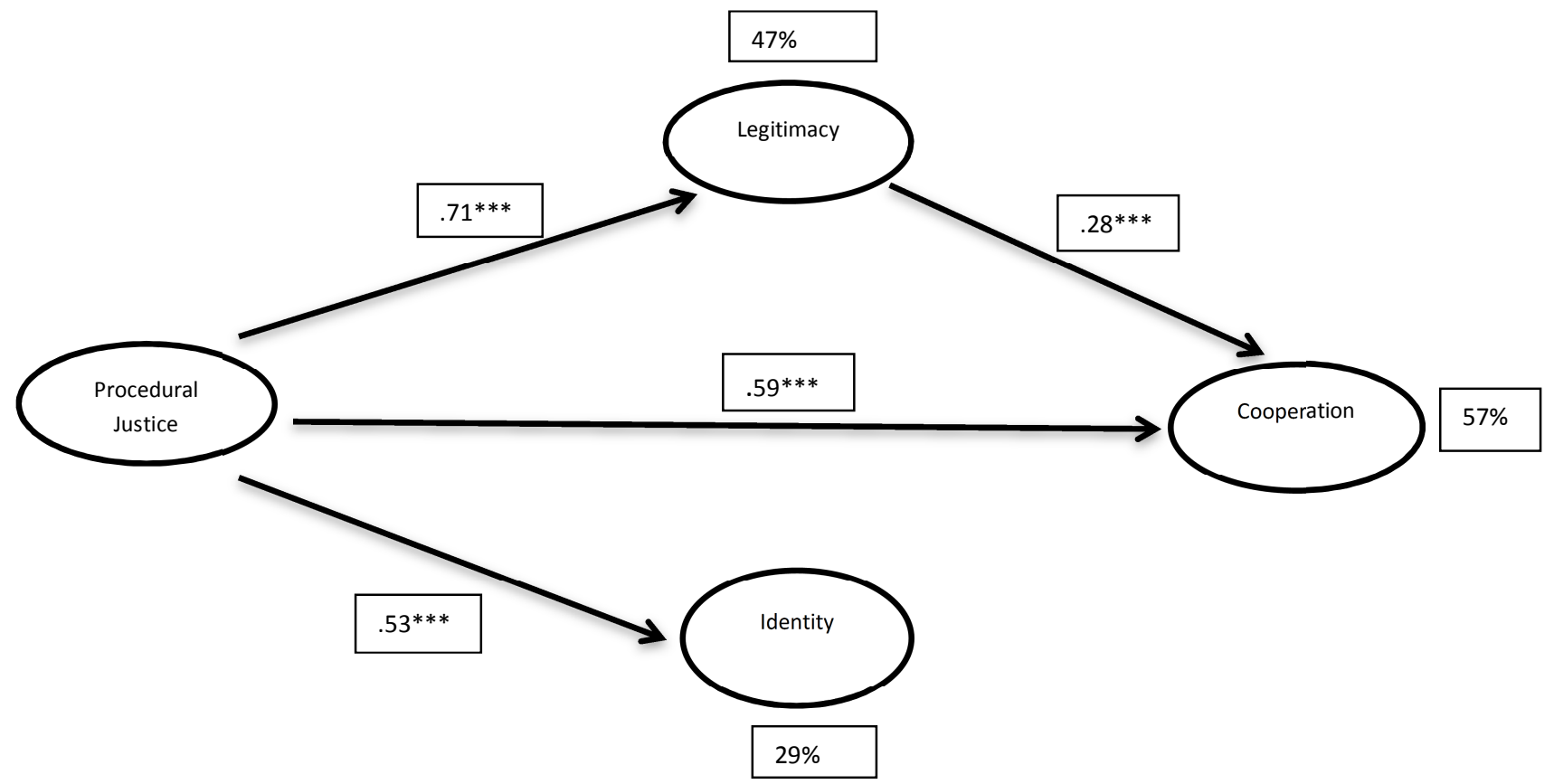

$\mathrm{Chi}^{2}=1181.43$
$\mathrm{df}=322$
$\mathrm{p}<.001$
$\mathrm{RMSEA}=.06$
$\mathrm{CFI}=.96$
$\mathrm{TLI}=.95$
$* * \mathrm{p}<.01$
$* * * \mathrm{p}<.001$
Coefficients are standardised values

Figure 1. SEM predicting Muslims' self-reported cooperation with police 